最後に, 発足50周年を迎えられた「比較経済体制学会」に対し, あらためて心よりのお祝いを申し 述べるとともに，今後のさらなるご発展をお祈りします．

以上.

（2012年 5 月 5 日）

\title{
学会50周年を祝う：歴史の深い刻印への感慨を込めて
}

日本ロシア・東欧研究連絡協議会代表幹事 袴田 茂樹

比較経済体制学会の発足50周年を心からお慶び申し上げると共に, これまで学会の維持, 発展に尽 力されてきた方々に, 大いなる敬意を表します。この学会の歩みを振り返りますと, 20 世紀の生々し い歴史変動のこの学会への深い刻印に思いを馳せざるを得ません.1963年に発足した「社会主義経済 研究会」, 1966年の「社会主義経済学会」への発展, 1993年の「比較経済体制学会」への変身を振り返 るだけで，激動の歴史と学問の関係に思いを致さざるを得ず，感無量の思いがあります.

私的な話で失礼ですが, この学会の前身, つまり最初の社会主義経済研究会の発足はちょうど私が 大学に入学した年であり, 社会主義経済学会の会則が定められた1967年10月は, 私が大学を卒業して モスクワ大学大学院に留学した時期と一致します. その頃私はまだ学会員ではありませんでしたが, 当時の日本の学生や知識人たちは, 社会主義体制やその経済のあり方について, 今日の若い人には想 像できないほど熱っぽい議論を闘わせたのを昨日のことのように覚えています。経済学は単なる学問 ではなく, 哲学や思想であり, 個々人の生き方の問題でもありました.

モスクワ大学に留学してソ連の学者や知識人たちと議論して感じたことは, ソ連の味気ない公式的 な社会主義論と比べると,「○○理論」とか「 $\triangle \triangle$ 学派」などと言われた日本の社会主義経済理論の方 が，はるかに精緻だということでした，私に言わせると，わが国のそれは，スコラ哲学的とも言える ほどの精緻さでした，現実をどれだけ反映していたかは別として，理論的な水準という点では，ある いは単にマルクスやレーニンなど正統派の社会主義論だけでなく, ウェーバー理論なども視野に置い た幅の広さなどにおいても, 日本の社会主義経済論の方がソ連の経済論よりもずっと水準も高く奥が 深いと感じたものでした。ただ，それら理論の最大の問題点は, 実際の社会主義経済の現実と, そし て結果的に資本主義の現実とも，血の通うリアルな接点を欠いていたということでしょう。ビーカー の中で純粋培養された緻密な理論と言えるかも知れません. これはまた, 当時のわが国の社会主義経 済論の致命的な欠陥でもありました.

ただ, 会員の方々の名誉のためにひとこと言い添えますと, その後最近に至るまで, 本学会員の研 究が, そのテーマに於いても方法論においても, たいへん多様かつ実証的な方向に進んだのも事実で す，そして，以前とは別の意味で，理論的にも精緻な研究も多くなりました．例えば，最近のロシア 経済に関する本学会員の研究に関しても, その実証性かつ理論的な綿密さにおいて, この分野での世 界の研究水準を突き抜けていると感じることも少なくありません.

比較経済体制学会への名称変更の背後には, もちろん, ソ連邦と社会主義陣営の崩壊という, 20 世 紀最大の政治・社会ドラマがあります. 本学会にとって, 研究対象そのものが崩壊・消滅したという, 深刻な事態に直面したわけです，学会が消滅しても不思議ではない状況です。しかし，学会のデータ を見ますと，会員数は1970年頃に100名を，1980年頃に200名を超えていますが，社会主義体制崩壊後 
の今日では約 270 名ということです，驚くべきことは，社会主義経済学会は，その研究対象が消滅した 後も, 学会の名称や研究分野を切り替え歴史の変化に柔軟に対応することによって, その勢いをさら に強めているということです，私もロシア・東欧学会の代表理事として，ロシア，東欧への関心が世 界的に薄れつつあるときに, 学会の活力を衰退させないための努力した経験があります.したがって, この比較経済体制学会の維持, 発展に尽力された方々の苦労も分かっているつもりです. 特異な歴史 的状況の中で, 研究対象を失った学会を変革し, それを維持, 発展させるということは, 並大抵のこ とではないでしょう。

世界は, 資本主義陣営, 社会主義陣営という冷戦時代の二元的構造から, 多元的世界に移行しまし た.この学会も, 単に社会主義経済を資本主義のそれと比べるという二元論的アプローチから, 多元 的世界における様々な経済体制を比較研究するというアプローチに転換して，学会の消滅や衰退を防 ぎました. 最近, 本学会で発表される研究テーマの多様性を考えると, この学会の大きな変化を感じ ざるを得ません，実際の歴史自体がドラマチックであったと同様に，この歴史に翻弄されながらも， 今日まで自己変身を遂げて生き延び発展してきた学会の歴史もたいへんドラマチックです.

私的なことにも触れさせて頂きましたが，このようなことに思いを馳せながら，学会の50年を振り 返りました。この学会の発展に尽力された方々, また時代の変化に応じて経済学を多様に発展させて 来た会員の方々に, 改めて敬意を表して，50周年のお祝いの言葉とさせて頂きます.

平成 24 年 9 月 17 日

\section{Economics as Social Science and the Role of Comparative Economics: "very-short paper" for the celebration of the 50th anniversary of the Japan Association for Comparative Economic Studies (JACES)}

President of the European Association for Comparative Economic Studies (EACES) Marcello Signorelli*

All sciences evolve over time thanks to new theoretical and empirical results. Progress in natural sciences (like Physics) largely depends on new "hard" (laboratory) results while evolution in the social sciences (like Sociology) derives from new "soft" findings. Social sciences (including Economics) focus on "complex systems", in particular, on the consequences of human and social behaviour and interactions; in addition, a significant emphasis is placed on the role of economic-institutional-social structures and dynamics in shaping the course of history. However, more than a century ago, especially with the diffusion of "General Economic Equilibrium" theory, the Economics profession, started on an ambitious path moving from the ambit of social sciences and attempting to approach the realm of the natural sciences (e.g. Vercelli, 1991). Was that evolution the beginning of a virtuous advancement toward a necessary rigorous and consistent apparatus or was it the first sign of a dangerous involution? ${ }^{1)}$ The answer to this question is not simple, but we can propose some observations. First of all, it should be noted that this evolution of Economics has not been linear, nor unchallenged; a significant exception was provided by Keynes who based his General Theory (1936) on the rejection of the ergodic axiom ${ }^{2)}$ (e.g. Davidson, 2012). Despite this, in the last half a century many Keynesians also substantially favoured or accepted the "ergodic hypothesis" for Economics (e.g. Samuelson, 1969), in addition to the economists of the non-Keynesian schools (e.g. Lucas and Sargent, 1981). ${ }^{3)}$ As argued, especially by some post-Keynesians, in an 